\title{
Profil kondisi fisik atlet senior Wushu Sanda Kediri dalam menghadapi Pekan Olahraga Provinsi (Porprov) Jawa Timur tahun 2019
}

\section{Profile of the physical condition of senior Wushu Sanda puslatkot Kediri atlet in provincial sports event (Porprov) East Jawa 2019}

\section{Anis Zawawi ${ }^{1}$ \& Rizki Burstiando ${ }^{2}$}

1,2Departemen Physical Education, Health, and Recreation, Universitas Nusantara PGRI Kediri, Jl. KH. Achmad Dahlan No 76, Mojoroto District, Kediri, East Java Province, 64112, Indonesia

Received: 13 January 2020; Revised: 16 April 2020; Accepted: 21 April 2020

\begin{abstract}
Abstrak
Penelitian ini berdasarkan problematika yang ada di Pusat Latihan Kota (Puslatkot) cabang olahraga Wushu tahun 2019 yakni minimnya ketersediaan data tentang kondisi fisik atlet menjadi faktor permasalahan bagi pelatih dalam menyusun program latihan. Penelitian ini bertujuan untuk mengetahui kondisi fisik atlet senior Wushu Sanda yang tergabung dalam Puslatkot Kota Kediri dalam menghadapi Pekan Olahraga Provinsi (Porprov) Jawa Timur tahun 2019. Penelitian yang dilaksanakan ini menggunakan metode deskriptif kuantitatif dengan menggunakan survey dan juga tes dan pengukuran. Instrumen yang digunakan dalam mengambil data merupakan instrumen tes yang sudah tersusun dalam buku panduan tes dan pengukuran dan sesuai dengan kebutuhan kodisi fisik yang digunakan dicabang olahraga Wushu Sanda. Hasil penelitian menunjukkan bahwa atlet dengan kondisi baik sekali sebanyak 15,31 $\%$, pada kategori baik sebanyak $35,71 \%$, kategori cukup sebanyak $22,45 \%$, kategori kurang sebanyak $13,25 \%$, dan pada kategori kurang sekali sebanyak $12,24 \%$. Dari hasil tes yang dilakukan, kondisi fisik atlet Wushu Sanda Kota Kediri dalam kategori baik. Selanjutnya bagi peneliti yang akan mengembangkan penelitian ini bisa mencakup lebih luas lagi, karena penelitian ini hanya terbatas pada atlet di kota kediri saja.
\end{abstract}

Kata kunci: atlet, kondisi fisik, wushu.

\begin{abstract}
This research is based on a problem in the City Training Center (Puslatkot) of the Wushu in 2019, namely the lack of availability of data on the physical condition of athletes is a problem factor for coaches in preparing training programs. This study aims to determine the physical condition of senior Wushu Sanda athletes who are members of the Kediri City Puslatkot in the face of the East Java Provincial Sports Week (Porprov) in 2019. The research carried out uses quantitative descriptive methods using surveys and also tests and measurements. The instrument used in retrieving data is a test instrument that has been arranged in a test and measurement guide book and is in accordance with the requirements of the physical conditions used in the Wushu Sanda branch of sport. The results showed that athletes with excellent condition were $15.31 \%$, in the good category were $35.71 \%$, the enough categories were as much as $12.24 \%$. From the results of tests conducted, the physical condition of the Wanda
\end{abstract}

Correspondence author: M. Anis Zawawi, Universitas Nusantara PGRI Kediri, Indonesia.

Email: zawawi@unpkediri.ac.id 
Sanda athlete in Kediri City is in the good category. Furthermore, researchers who will develop this research can cover more broadly, because this research is only limited to athletes in the city of Kediri.

Keywords: athletes, physical condition, wushu.

\section{PENDAHULUAN}

Pembangunan suatu negara tergantung pada Sumber Daya Manusia (SDM) yang mencakup beragai bidang merupakan salah satu syarat mutlak (Siregar, 2017). SDM merupakan salah satu aset negara dalam rangka pembangunan dalam bidang apapun termasuk olahraga (Suherman, 2012). Pembentukan dan pembinaan prestasi dalam olahraga merupakan bagian kecil dari usaha pemerintah dengan mewujudkan pusat pelatihan. Atlet-atlet yang dipilih untuk pembinaan di pusat pelatihan diambil dari tingkat daerah. Dengan adanya pusat pelatihan pembinaan maka proses pembinaan menjadi terstruktur dan termonitor. Pada pusat pelatihan akan diberikan sebuah pelatihan menurut kecabangan olahraga masing-masing, sehingga ketika suatu saat mengikuti event olahraga, maka seleksi atlet akan lebih terorganisir dengan adanya pusat pelatihan (Herpandika, Yuliawan, \& Rizky, 2019).

Dalam rangka meraih prestasi yang maksimal pada setiap kejuaraan, tentunya banyak yang harus disiapkan dan diperhatikan. Tanpa didukung dengan kondisi fisik yang prima, pencapaian prestasi puncak akan mengalami banyak kendala. Salah satunya atlet tidak mampu mempertahankan performa dalam waktu yang relatif lama (Mansur, 2016). Pencapaian prestasi yang baik pastinya harus didukung banyak faktor, baik dari segi fisik maupun nonfisik. Faktor fisiologi berperan aktif dalam merancang program olahraga yang diinginkan (Anggriawan, 2015). Hal ini senada dengan apa yang disampaikan oleh Utami (2015), bahwasannya faktor fisiologi sangat berperan dalam mencapai prestasi olahraga, terutama pada kondisi jantung dan paru. Selain itu, faktor konsentrasi juga memengaruhi prestasi olahraga (Nuryadi, Negara, Juliantine, Slamet, \& Gumilar, 2018). Disamping itu juga, prestasi olahraga juga tidak lepas dari peran nilai karakter (Mirhan, 2016). 
Pelatih harus menyiapkan semua aspek yang dibutuhkan semua atlet baik fisik, taktik maupun mental (Ioannis N. Kostikiadis, Spyridon Methenitis, Athanasios Tsoukos, Panagiotis Veligekas, 2018). Dalam dunia seni bela diri, dikenal dengan seni olahraga beladiri yang halus dan kasar, pada wushu sendiri ada Tao Lu dan Sanda (Oliver O'Donovan, Jeanette Cheung, Maria Catley, 2006). Dalam menyiapkan seorang atlet, yang paling mendasar adalah faktor kondisi fisik atlet. Hal ini sesuai yang disampaikan oleh Utami (2015), yang menyebutkan bahwa fisilogis dan kemampuan kondisi fisik merupakan pondasi awal dalam kaitannya dengan prestasi olahraga. Selanjutnya, upaya meningkatkan prestasi oahraga perlu terus dilaksanakan dalam kaitannya dengan pembinaan melalui pencarian dan pemanduan bakat, pembibitan, pendidikan dan pelatihan olahraga prestasi yang didasarkan pada ilmu pengetahuan dan teknologi secara efektif dan efisien serta peningkatan kualitas olahraga (Ulum, 2013). Olahraga wushu merupakan olahraga yang membutuhkan faktor fisik yang bagus baik dinomor tanding maupun seni. Dalam hal ini komponen kondisi fisik yang dibutuhkan oleh atlet khususnya Wushu diantaranya kekuatan otot tungkai, kelentukan, power tungkai, kelincahan, daya tahan jantung dan paru serta kecepatan. Semua aspek tersebut sangatlah penting dalam menunjang performa atlet agar dalam setiap materi/teknik yang diberikan akan dengan mudah diterima dan bisa menirukan baik dalam nomor seni maupun tanding, karena olahraga ini sangat bergantung pada kondisi fisik seorang atlet (Kuan \& Roy, 2007). Olahraga semacam ini sangatlah berantung juga pada daya tahan jantung, sehingga dengan ini semua teknik yang diajarkan bisa dengan mudah diikti oleh atlet (Ribeiro, Bruno Ogoday S. D. de Castro, Caio S. Rosa, \& Oliveira, 2006). Berkaca pada pelaksanaan Porprov V yang diselenggarakan di Banyuwangi, Kota Kediri menempati peringkat ketiga dalam perolehan medali yaitu 32 emas, 37 perak, 45 perunggu dengan 247 poin (Pacitanku, 2015). Pada perhelatan Porprov VI tahun 2019 cabang olahraga Wushu diselenggarakan di Kabupaten Lamongan. Beberapa atlet yang dirasa berbakat dan layak berprestasi telah dipanggil 
melalui jalur seleksi untuk mengikuti pemusatan latihan yang tergabung dalam Puslatkot Kota Kediri sejak tahun 2017. Melihat dari riwayat prestasi cabang Wushu Kota Kediri, prestasi yang diraih atlet-atlet Wushu Sanda Kota Kediri sangatlah membanggakan. Banyak kejuaraan daerah yang sudah diperoleh para atlet sanda maupun Tao Lu. Maka dari itu, target yang dibebankan kepada tim wushu Kota Kediri diberbagai kejuaraan juga sangat tinggi, apalagi tim Wushu Kota Kediri selalu mendapat dukungan penuh dari pemerintah Kota Kediri melalui KONI Kota Kediri. Berawal dari itulah mengapa tim wushu selalu mempersiapkan segala sesuatu jauh- jauh hari untuk menghadapi sebuah kejuaraan, termasuk salah satunya adalah kondisi fisik para atlet.

Penelitian yang menitikberatkan pada hasil kondisi fisik atlet ini merupakan terobosan yang dilakukan kepada tim Wushu terutama yang tergabung dalam Puslatkot Porprov 2019. Dengan adanya ini para pelatih ataupun official bahkan atlet tahu akan pentingnya faktor kondisi fisik yang harus dimiliki bagi seorang atlet. Selanjutnya untuk lebih memaksimalkan prestasi Wushu Kota Kediri, maka perlu ditingkatkan untuk memeperhatikan faktor yang memengaruhi prestasi atlet, tidak hanya mengedepankan faktor fisik saja.

\section{METODE}

Jenis penelitian ini adalah deskriptif kuantitatif, yang mendeskrisikan fenomena tertentu dengan menggunakan metode survey. Menurut Maksum (2009), penelitian deskriptif adalah penelitian yang dilakukan untuk menggambarkan gejala, fenomena, kondisi atau peristiwa tertentu. Sedangkan penelitian kuantitatif menurut (Suharsimi, 2013), adalah sesuai dengan namanya banyak dituntut menggunakan angka mulai dari pengumpulan data, penafsiran dari data tersebut, serta penampilan dari data tersebut.

Untuk memperoleh data yang sesuai maka dalam penelitian ini menggunakan metode survey dan teknik tes dan pengukuran (Fenanlampir \& Muhyi, 2015). Metode ini dimaksudkan untuk mengumpulkan data-data mengenai kondisi fisik dengan menggunakan 
teknik tes. Macam-macam tes kondisi fisik yang akan dilaksanakan antara yaitu:

1. Kekuatan otot tungkai dengan menggunakan Leg Dynamometer.

2. Power tungkai dengan menggunakan vertical jump

3. Power Otot lengan menggunakan Medicine Ball Put

4. Kekuatan otot lengan dengan Push Up

5. Kelincahan dengan menggunakan Shuttle Run

6. Daya Tahan jantung dan paru menggunakan tes Multistage Fitnes Tes (MFT)

7. Fleksibilitas dengan menggunakan Flexiometer

Data yang diperoleh tiap-tiap item tes merupakan data kasar dari hasil tiap tes yang dicapai. Hasil kasar tersebut diubah menjadi nilai t-skor dengan rumus t-skor sebagai berikut:

$T=10\left(\frac{M-R}{S D}\right)+50$ (data inversi)

$T=10\left(\frac{M-X}{S D}\right)+50$ (data reguler)

Keterangan:

$\mathrm{T} \quad=$ nilai $\mathrm{t}$ skor

$\mathrm{M} \quad=$ nilai rata-rata kasar

$\mathrm{X}=$ nilai data kasar

$\mathrm{SD}=$ standar deviasi data kasar

Data yang sudah diubah ke dalam t-skor, kemudian data dimaknai, yaitu dengan mengkategorikan data. Pengkategorian dikelompokkan menjadi 5 ketegori (Azwar, 2012) yaitu : baik sekali, baik, cukup, kurang, kurang sekali. Pengkategorian menggunakan acuan 5 batas normal (Sudjiono, 2011), adalah sebagai berikut:

Tabel 1. Skor Baku Kategori

\begin{tabular}{ccc}
\hline No & Rentang Norma & Kategori \\
\hline 1 & $\mathrm{X} \geq \mathrm{M}+1,5 \mathrm{SD}$ & Baik Sekali \\
\hline 2 & $\mathrm{M}+0,5 \mathrm{SD} \leq \mathrm{X}<\mathrm{M}+1,5 \mathrm{SD}$ & Baik \\
\hline 3 & $\mathrm{M}-0,5 \mathrm{SD} \leq \mathrm{X}<\mathrm{M}+0,5 \mathrm{SD}$ & Cukup \\
\hline 4 & $\mathrm{M}-1,5 \mathrm{SD} \leq \mathrm{X}<\mathrm{M}-0,5 \mathrm{SD}$ & Kurang \\
\hline 5 & $\mathrm{X}<\mathrm{M}-1,5 \mathrm{SD}$ & Kurang Sekali \\
\hline
\end{tabular}


Langkah selanjutnya setelah data diperoleh adalah menganalisis data untuk menarik kesimpulan dari penelitian yang dilakukan. Analisis data yang digunakan dari penelitian ini menggunakan teknik analisis deskriptif kuantitatif dengan presentase. Menurut (Sugiyono, 2016) rumus yang digunakan adalah sebagai berikut :

$$
P=\left(\frac{f}{N}\right)+100 \%
$$

Keterangan:

$\mathrm{P}=$ presentase yang dicari

$F=$ frekuensi

$\mathrm{N}=$ jumlah responden

\section{HASIL}

1. Kondisi Fisik Secara Keseluruhan

Penelitian ini melibatkan atlet Wushu Kota Kediri berjumlah 14 atlet. Semua subyek yang diteliti dilakukan tes dan pengukuran, meliputi fleksibilitas togok, kelincahan, daya tahan, kekuatan otot tungkai, kekuatan otot lengan, power otot tungkai, dan power otot lengan. Hasil tes secara keseluruhan disajikan pada tabel 2 sebagai berikut.

Tabel 2. Data Hasil Komponen Kondisi Fisik Atlet Wushu Kota Kediri

\begin{tabular}{cccc}
\hline No. & Norma & Hasil & Persentase \\
\hline 1 & Baik Sekali & 3 & 15,31 \\
\hline 2 & Baik & 6 & 35,71 \\
\hline 3 & Cukup & 3 & 22,45 \\
\hline 4 & Kurang & 1 & 13,25 \\
\hline 5 & Kurang Sekali & 1 & 13,25 \\
\hline
\end{tabular}

Berdasarkan hasil komponen kondisi fisik pada tabel 2 dapat diketahui bahwa tingkat kondisi fisik atau profil kondisi fisik yang dimiliki oleh atlet Kota Kediri yang termasuk dalam kondisi baik sekali sebesar $15,31 \%$, pada kategori baik sebesar 35,71\%, kategori cukup sebesar $22,45 \%$, kategori kurang sebesar $13,25 \%$ dan pada kategori kurang sekali sebesar $12,24 \%$. 
2. Deskripsi Masing-masing Tes

Dari hasil analisis yang sudah dilakukan kepada atlet Wushu Kota Kediri, dijabarkan analisis deskripsinya sebagai berikut:

a. Fleksibilitas Togok

Hasil hasil pengumpulan data kondisi fisik atlet Wushu Kota Kediri untuk fleksibilitas togok yaitu:

Tabel 3. Data Hasil Tes Fleksibilitas Togok

\begin{tabular}{lccc}
\hline \multicolumn{1}{c}{ Norma } & Konversi & Hasil & Persentase \\
\hline Baik Sekali & 20.5 & 1 & 7.14 \\
Baik & 19.0 & 3 & 21.43 \\
Cukup & 18.0 & 1 & 7.14 \\
Kurang & 15.5 & 3 & 21.43 \\
Kurang Sekali & 13.5 & 6 & 42.86 \\
\hline \multicolumn{1}{r}{} & & 14 & 100 \\
\hline
\end{tabular}

Berdasarkan tabel 3 dapat diketahui bahwa penilaian tes pengukuran fleksibilitas togok terhadap 14 pemain, 1 atlet pada kategori baik sekali dengan persentase 7,14\%, 3 atlet pada kategori baik dengan persentase 21,43\%, 1 atlet pada kategori cukup dengan persentase $7,14 \%$, 3 atlet pada kategori kurang dengan persentase $21,43 \%$, dan 6 atlet pada kategori kurang sekali dengan persentase $42,86 \%$.

b. Kelincahan

Hasil hasil pengumpulan data kondisi fisik atlet Wushu Kota Kediri untuk kelincahan yaitu:

Tabel 4. Data Hasil Tes Kelincahan

\begin{tabular}{|c|c|c|c|}
\hline Norma & Konversi & Hasil & Persentase \\
\hline Baik Sekali & $<12.42$ & 5 & 35.71 \\
\hline Baik & $12.43-14.09$ & 7 & 50.00 \\
\hline Cukup & $14.10-15.74$ & - & 0.00 \\
\hline Kurang & $15.75-17.39$ & 2 & 14.29 \\
\hline Kurang Sekali & $<17.40$ & - & 0.00 \\
\hline \multicolumn{2}{|c|}{ Jumlah } & 14 & 100 \\
\hline
\end{tabular}

Berdasarkan tabel 4 dapat diketahui bahwa penilaian tes pengukuran kelincahan terhadap 14 pemain, 5 atlet pada kategori baik sekali dengan persentase $35,71 \%, 7$ atlet pada kategori baik dengan 
persentase $50 \%$, dan 2 atlet pada kategori kurang dengan persentase $14,29 \%$.

c. Daya Tahan (VO2Max)

Hasil hasil pengumpulan data kondisi fisik atlet Wushu Kota Kediri untuk daya tahan (Vo2max) yaitu:

Tabel 5. Data Hasil Tes Daya Tahan (Vo2max)

\begin{tabular}{|c|c|c|c|}
\hline Norma & Konversi & Hasil & Persentase \\
\hline Baik Sekali & $>51,6$ & - & - \\
\hline Baik & $42,6-51,5$ & 1 & 7.14 \\
\hline Cukup & $33,8-42,5$ & 7 & 50.00 \\
\hline Kurang & $25,0-33,7$ & 6 & 42.86 \\
\hline Kurang Sekali & $<25$ & - & - \\
\hline & & 14 & 100 \\
\hline
\end{tabular}

Berdasarkan tabel 5 dapat diketahui bahwa penilaian tes pengukuran daya tahan (VO2Max) terhadap 14 pemain, 1 atlet pada kategori baik dengan persentase 7,14\%, 7 atlet pada kategori cukup dengan persentase $50 \%$, dan 6 atlet pada kategori kurang dengan persentase $42,86 \%$.

d. Kekuatan Otot Tungkai

Hasil hasil pengumpulan data kondisi fisik atlet Wushu Kota Kediri untuk kekuatan otot tungkai yaitu:

Tabel 6. Data Hasil Tes Kekuatan Otot Tungkai

\begin{tabular}{|c|c|c|c|}
\hline Norma & Konversi & Hasil & Persentase \\
\hline Baik Sekali & $>219,5$ & - & 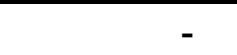 \\
\hline Baik & $171,5-219,5$ & - & - \\
\hline Cukup & $127,5-171,5$ & 1 & 7.14 \\
\hline Kurang & $81,5-127,5$ & 9 & 64.29 \\
\hline Kurang Sekali & $<81,5$ & 4 & 28.57 \\
\hline \multicolumn{2}{|c|}{ Jumlah } & 14 & 100 \\
\hline
\end{tabular}

Berdasarkan tabel 6 dapat diketahui bahwa penilaian tes pengukuran kekuatan otot tungkai terhadap 14 pemain, 1 atlet pada kategori cukup dengan persentase 7,14\%, 9 atlet pada kategori kurang dengan persentase $64,29 \%$, dan 4 atlet pada kategori kurang sekali dengan persentase $28,57 \%$. 
e. Kekuatan Otot Lengan

Hasil hasil pengumpulan data kondisi fisik atlet Wushu Kota Kediri untuk kekuatan otot lengan yaitu:

Tabel 7. Data Hasil Tes Kekuatan otot Lengan

\begin{tabular}{|c|c|c|c|}
\hline Norma & Konversi & Hasil & Persentase \\
\hline Baik Sekali & $>70$ & & \\
\hline Baik & $54-69$ & 6 & 42.86 \\
\hline Cukup & $35-53$ & 8 & 57.14 \\
\hline Kurang & $22-34$ & - & - \\
\hline Kurang Sekali & $<21$ & - & - \\
\hline \multicolumn{2}{|c|}{ Jumlah } & 14 & 100 \\
\hline
\end{tabular}

Berdasarkan tabel 7 dapat diketahui bahwa penilaian tes pengukuran kekuatan otot lengan terhadap 14 pemain, 6 atlet pada kategori baik dengan persentase $42,86 \%$, dan 8 atlet pada kategori cukup dengan persentase $57,14 \%$.

\section{f. Power Otot Tungkai}

Hasil hasil pengumpulan data kondisi fisik atlet Wushu Kota Kediri untuk power otot tungkai yaitu:

Tabel 8. Data Hasil Tes Power Otot Tungkai

\begin{tabular}{|c|c|c|c|}
\hline Norma & Konversi & Hasil & Persentase \\
\hline Baik Sekali & $>43,18$ & 9 & 64.29 \\
\hline Baik & $38,1-43,17$ & 1 & 7.14 \\
\hline Cukup & $33,02-38,0$ & 3 & 21.43 \\
\hline Kurang & $20,32-33,01$ & 1 & 7.14 \\
\hline Kurang Sekali & $7,62-20,31$ & - & - \\
\hline \multicolumn{2}{|c|}{ Jumlah } & 14 & 100 \\
\hline
\end{tabular}

Berdasarkan tabel 8 dapat diketahui bahwa penilaian tes pengukuran power otot tungkai terhadap 14 pemain, 9 atlet pada kategori baik sekali dengan persentase $64,29 \%, 1$ atlet pada kategori baik dengan persentase 7,14\%,31 atlet pada kategori cukup dengan persentase $21,43 \%$, dan 1 atlet pada kategori kurang dengan persentase $7,14 \%$.

g. Power Otot Lengan

Hasil hasil pengumpulan data kondisi fisik atlet wushu Kota Kediri untuk power otot lengan yaitu: 
Tabel 9. Data Hasil Tes Power Otot Lengan

\begin{tabular}{|c|c|c|c|}
\hline Norma & Konversi & Hasil & Persentase \\
\hline Baik Sekali & $>5,90$ & - & - \\
\hline Baik & $5,11-5,51$ & 2 & 14.29 \\
\hline Cukup & $3,14-4,72$ & 8 & 57.14 \\
\hline Kurang & $1,96-2,75$ & 4 & 28.57 \\
\hline Kurang Sekali & $0-1,57$ & - & - \\
\hline \multicolumn{2}{|c|}{ Jumlah } & 14 & 100 \\
\hline
\end{tabular}

Berdasarkan tabel 9 dapat diketahui bahwa penilaian tes pengukuran power otot lengan terhadap 14 pemain, 2 atlet pada kategori baik dengan persentase $14,29 \%, 8$ atlet pada kategori cukup dengan persentase $57,14 \%$, dan 4 atlet pada kategori kurang dengan persentase $28,57 \%$.

\section{PEMBAHASAN}

Penelitian ini bertujuan untuk mengkaji kondisi fisik atlet senior Wushu Sanda Kota Kediri yang tergabung dalam Puslatkot Poprov 2019. Hasil penelitian menunjukkan bahwa atlet yang dalam kondisi baik sekali sebesar $15,31 \%$, pada kategori baik sebesar $35,71 \%$, kategori cukup sebesar $22,45 \%$, kategori kurang sebesar $13,25 \%$ dan pada kategori kurang sekali sebesar $12,24 \%$. Maka dapat disimpulkan bahwa kondisi fisik atlet senior Wushu Sanda Kota Kediri dalam kategori baik, yaitu dengan presentase sebesar $35,71 \%$.

Analisis yang dilakukan dengan presentase dalam perolehan pengambilan data, sehingga didapatkan hasil penelitian yang menunjukkan bahwa kondisi fisik atlet senior wushu sanda dalam kategori baik dengan perolehan $35,71 \%$. Artinya kondisi fisik yang baik dipengaruhi oleh proses latihan yang baik pula, sehingga dalam mencapai tujuan latihan dapat dicapai dengan maksimal. Kajian kondisi fisik dalam penelitian ini jika melihat dari hasil tes sangat jelas keadaan atlet menunjukkan kategori baik. Jadi dalam proses latihan secara terprogram dapat memberikan gambaran jelas, bahwa kondisi fisik atlet tergantung dari proses latihan. 
Atlet dengan nilai kondisi fisik yang baik akan lebih cepat dalam proses pemulihan maupun saat pertandingan (Al Ayubi, 2017) sehingga akan menjadikan atlet bergerak dan bermain menjadi efektif dan efisien untuk melakukan teknik gerakan yang tepat (Azidman, L., Arwin, 2017). Kondisi fisik merupakan sebuah keadaan tubuh yang bisa berubah-ubah tergantung dari penanganan dan komponen-komponen tubuh. Artinya kondisi fisik dapat secara mutlak dilatih dan ditingkatkan sesuai dengan porsi masin-masing individu dengan latihan yang terstruktur, teratur, dan progresif, sehingga peningkatan dalam masing-masing komponen akan saling melengkapi.

Melihat dari beberapa pembahasan di atas, maka status kondisi fisik diperlukan untuk memonitoring keadaan atlet yang telah dilatih. Maka dari itu pada tim wushu sanda memberikan proses latihan yang panjang sehingga nantinya pada ajang Porprov 2019 tim ini bisa encapai target yang dibebankan oleh KONI Kota Kediri.

\section{KESIMPULAN}

Dari hasil yang diperoleh, bahwasannya keadaan kondisi fisik atlet yang tergabung dalam Puslatkot Porprov 2019 berada dalam kondisi yang baik, walaupun masih ada beberapa atlet yang dalam keadaan kurang, karena atlet tersebut merupakan atlet yang baru bergabng dengan tim wushu sanda ota kediri. Dengan melihat hasil yang sudah ada, maka perlu diketahui bagi atlet maupun tim pelatih bahwasannya salah satu faktor terpenting dalam olahraga yaitu faktor kondisi fisik, untuk itu maka semua tim harus memperhatikan kondisi fisik para atletnya agar program latihan yang diharapkan bisa berjalan dengan baik.

\section{REFERENSI}

Adziman, L., Arwin, A., \& Syafrial, S. (2017). Profil Kondisi Fisik Pemain Sepak Bola Sma Negeri 1 Kaur. KINESTETIK, 1(1).

Al Ayubi, B. (2017). Profil Kondisi Fisik Pemain Liga Pendidikan Indonesia (LPI) Sepakbola Universitas Negeri Yogyakarta (UNY) dalam Menghadapi Liga Pendidikan Indonesia (LPI) Tahun 2017. Jurnal Student UNY.

Anggriawan, N. (2015). Peran fisiologi olahraga dalam menunjang 
prestasi. Jorpres (Jurnal Olahraga Prestasi), 11(2).

Azwar, S. (2012). Penyusunan Skala Psikologi. Yogyakarta: Pustaka Pelajar.

Fenanlampir, A, Muhyi , M, F. (2015). Tes \& Pengukuran dalam Olahraga (1st ed.). Yogyakarta: Andi Ofset.

Herpandika, R. P., Yuliawan, D., \& Rizky, M. Y. (2019). The analysis of physical conditions of Puslatkot athletes of Kediri city for "Kediri Emas" in porprov 2019. Jurnal SPORTIF: Jurnal Penelitian Pembelajaran. https://doi.org/10.29407/js_unpgri.v5i2.13758

loannis N. Kostikiadis, Spyridon Methenitis, Athanasios Tsoukos, Panagiotis Veligekas, G. T. and G. C. B. (2018). The Effect of Short-Term Sport-Specific Strength and Conditioning Training on Physical Fitness of Well-Trained Mixed Martial Arts Athletes. Journal of Sports Science and Medicine, 17, 348-358.

Kuan, G., \& Roy, J. (2007). Goal profiles, mental toughness and its influence on performance outcomes among Wushu athletes. Journal of sports science \& medicine, 6(CSSI-2), 28.

Maksum, A. (2009). Metodologi Penelitian dalam Olahraga. Surabaya: Universitas Negeri Surabaya, Fakultas IImu Keolahragaan.

Mansur, M. (2016). Pengaruh Complex Training manipulation terhadap Peningkatan Power Otot Tungkai pada Mahasiswa Prodi Pko Fik Uny. Jorpres (Jurnal Olahraga Prestasi), 12(1).

Mirhan, J. B. K. J. (2016). Hubungan Antara Percaya Diri Dan Kerja Keras Dalam Olahraga Dan Keterampilan Hidup. Jorpres (Jurnal Olahraga Prestasi), 12(1).

Nuryadi, N., Negara, J. D. K., Juliantine, T., Slamet, S., \& Gumilar, A. (2018). Hubungan Kebugaran Jasmani dengan Kemampuan Konsentrasi dan Respon Kortisol. Jurnal Pendidikan Jasmani Dan Olahraga. https://doi.org/10.17509/jpjo.v3i2.12578

Oliver O'Donovan, Jeanette Cheung, Maria Catley, A. H. M. and P. H. S. (2006). An Investigation of Leg and Trunk Strength and Reaction Times of Hard-Style Martial Arts Practitioners. Journal of Sports Science and Medicine, 5-12.

Pacitanku. (2015). Hasil Akhir Porprov Jatim V: Surabaya Juara Umum, Pacitan Peringkat $26 . \quad$ Retrieved from https://pacitanku.com/2015/06/14/hasil-akhir-porprov-jatimvsurabaya-juara-umum-pacitan-peringkat-26/

Ribeiro, J. L., , Bruno Ogoday S. D. de Castro, Caio S. Rosa, R. R., \& Oliveira, B. and A. R. (2006). Heart Rate and Blood Lactate Responses to Changquan and Daoshu Forms of Modern Wushu. Journal of Sports Science and Medicine, 1-4.

Sarifudin Najib Kurniawan. (2018). Profil Biomotor Atlet Wushu Sanda Di Club Sanbo (Wushu Sanda - Muaythai) Kabupaten Magelang. 
Universitas Negeri Yogyakarta.

Siregar, R. (2017). Sumber Daya Manusia dalam Pembangunan Nasional. SEMNASFIS Universitas Negeri Medan, 378-831.

Sudjiono, A. (2011). Pengantar Evaluasi Pendidikan. Jakarta: Rajawali Pers.

Sugiyono. (2016). Metode Penelitian Kuantitatif, Kualitatif dan R\&D. CV Alfabeta.

Suharsimi, A. (2013). Prosedur Penelitian: Suatu Pendekatan Praktik (Edisi Revisi). Jakarta: Rineka Cipta. https://doi.org/10.1017/CBO9781107415324.004

Suherman, E. (2012). Kiat Sukses Membangun SDM Indonesia. Bandung: CV Alfabetta.

Ulum, A. S. (2013). Pembinaan olahraga bela diri wushu di kota Salatiga tahun 2013. ACTIVE: Journal of Physical Education, Sport, Health and Recreation, 2(10).

Utami, D. (2015). Peran Fisiologi Dalam Meningkatkan Prestasi Olahraga Indonesia Menuju Sea Games. Jurnal Olahraga Prestasi. 